\title{
A Study of Insect Diversity in Different Habitats Found in Nearby Locality of Raipur, Chhattisgarh
}

\author{
Prerana Prakhar*1, Dr. Manoj Singh ${ }^{2}$, Dr. R. K. Agrawal $^{2}$ \\ ${ }^{1}$ Research Scholar, Kalinga University, Raipur, Chhattisgarh, India. \\ ${ }^{2}$ Department of Zoology, Kalinga University, Nava Raipur, Chhattisgarh, India
}

\begin{abstract}
Article Info

Volume 8, Issue 5

Page Number : 467-468

Publication Issue

September-October-2021

\section{Article History}

Accepted : 10 Oct 2021

Published : 18 Oct 2021

Insects are most diverse, successful and dominant taxon of the animal kingdom. They are found in almost every habitat across the globe. It is due to their diverse body size, habit, fecundity, different modes of respiration, food diversity etc. Because of these diverse characteristics, they became an important component of our ecosystem. They have significant influence on agriculture, human health and natural resources. This was the main reason for analysing the status of insects' diversity across Raipur city. During this study various species of insects were collected and identified for estimating the insect species diversity and abundance in the different types of habitats found in Raipur. Insects were collected from various habitats like public park, gardens, fruit \& vegetable market, agricultural fields etc. Total 603 species from 38 families, from 10 orders of insects were obtained during the sampling from January2019 to February 2020. The contributions of different orders were as follows: Lepidoptera (6), Coleoptera (6), Hemiptera (6), Hymenoptera (5), Orthoptera (3), Dermaptera (1), Diptera (6), Odonata (3) and Isoptera (1) and Mantodea(1) were collected. Diptera were having highest species diversity which was followed by Hymenoptera. Biodiversity of insects were highest in gardens and agricultural fields. The diverse habitats present in and around Raipur provide a favorable climate for insects.

Keywords : Raipur, Insect, Orders, Habitat, Species diversity.
\end{abstract}

\section{INTRODUCTION}

Insects are the largest one and most diverse, successful and dominant taxon group on the earth. Because of their diversity they play an important role in ecology and influence on agriculture, human health and natural resources. Insects are the hexapod invertebrates from class - insecta, phylum Arthropoda and kingdom - Animalia (Linnaeus, 1758). Insect biodiversity is the variability among living organisms from all sources including terrestrial, marine and other aquatic ecosystems. They possess an amazing diversity in size and the ability to fly permits them to run away from the enemies and scatter to 
new environment as they got a protective shell or exoskeleton. Insects have a nervous system that makes them similar to be ours like they can see, hear, smell, taste and feel. There are different kinds of insects according to their habits and habitats are as follows -

- $\quad$ Beetles - (Coleopterans) - front wings changed into a hard shell to protect back wings.

- Butterflies and moths (Lepidopteron) - large often colourful wings.

- $\quad$ Flies (Dipterans) - have only two wings.

- Ants, bees and wasps (Hymenoptera) - mostly in large colonies, sometimes stringer.

- True Bugs (Hemipteran) - have beak, a kind of mouth like drinking straw.

- Grasshoppers (Orthopteran) - jump with their legs and eat grass.

- Odonatan, dragonflies and damselflies are predator of other insects.

The biodiversity consists of three major parts genetic diversity species diversity and ecosystem diversity (smith 1996). The insect community in the habitats source could affect the species survival and further affect the species composition and distribution pattern of insect community. In the current condition due to the lack of oxygen level or may be lack of flying vertebrates it is very difficult to protect the whole world. So the best method of conservation is to protect the species, communities and their living places (Kocatas, 2004).

The biological diversity in other word biological richness is explained in a different ways according to different authors as - Magurran (2004) defined the biodiversity as a particular area. He said that biodiversity studies compare the diversity of two different areas and measure the changes in certain area depending on the number of species. The insect possess an amazing diversity in size and shape their ability to fly help them to defense from enemies and scatter a new environment as exoskeleton, protective cell etc. They have a fine nervous system that makes them able to see, hear, taste and feel. Vegetation in this area are trees, shrubs, crops, fruits crops, grasses, medicinal plants. The entomofauna are most successful and dominate group in the world they can survive anywhere due to small size, persistent habit, fecundity, aerial respiration, food diversity and protective devices etc. In this study area different insect orders i.e. Lepidoptera, Coleopteran, Hymenoptera, Hemiptera, Diptera, Orthoptera, Mantodea, Odonat. The total number of actually described insects 9, 65,431 - 10, 15,897 and that of hexapod 9048 (Chapman). Approx. 60,000 - 70,000 insect species known from India which is about $7-10 \%$ of the world's insect fauna. But Due to endemism it is unique which is about third of the known species. The main aim of this study is to collect and identify the insect species to know their diversity richness and abundance in the nearby locality of Raipur which were collected.

\section{Method and Material}

The present investigation was undertaken from agricultural farm, fruit and vegetable market, garden and other nearest locality of Santoshi Nagar which is a crowded area of Raipur closer to city and villages both and Various insect species were collected from the Kalinga university campus in and around between morning (8:00-10:00) to evening (15:00-17:00) hrs in the month of January to December to know the diversity of insects in Raipur. Insects were collected live from the sampling site by hand picking, shaking or beating etc. equipment used for collection are Hair brush, Forceps, Stick, Hand net, Killing bottle. After the collection, insects were transferred into the killing bottle. A cylindrical glass jar is used to make the killing bottle. The dead insects use to transfer into boxes for temporary storage. The sacrificed insects then properly pinned by steel pins and kept for proper drying. Naphthalene balls are placed inside the insect boxes to prevent the attack of fungus. 


\section{Sampling Processors}

Hemiptera were collected by aerial nets (in flight) sweeping nets (low vegetation), and beating of shrubs using long stick and a cloth on the ground collect the falling insects. Sweeping or beating was performed 56 times per plant. Collected materials were kept in 70\% alcohol for identification. Orthoptera were collected with help of aerial net and butterfly net, and handpicking with the help of large forceps. Hymenoptera and coleopteran were collected by beating \& sweeping. The part of the plant was beaten with a stick with downwards strokes to free them. This was done at least $4-5$ times. Sweep nets were also used to trap some larger flying hymenopterans. Collected specimens were either kept in vials with 70\% alcohols or killed in killing bottles. Adult butterflies were netted from various places on the wings or when settled on flowers, puddles and over - ripe fruits. After killing the samples were taken in the laboratory for identification.

\section{RESULT AND DISCUSSION}

Why insect biodiversity matters and how the rapid evolution of insect species is affecting us all. It presents a scene-setting overview of the value of insects through examples of regional biodiversity, taxon biodiversity, tools and approaches, and management and conservation to a historical view of the quest for the true number of insect species which is the wide variety in type and number and their evolutionary relationships. The biology and ecology of insects is the only way to sustainably manage ecosystems in an ever changing global environment.
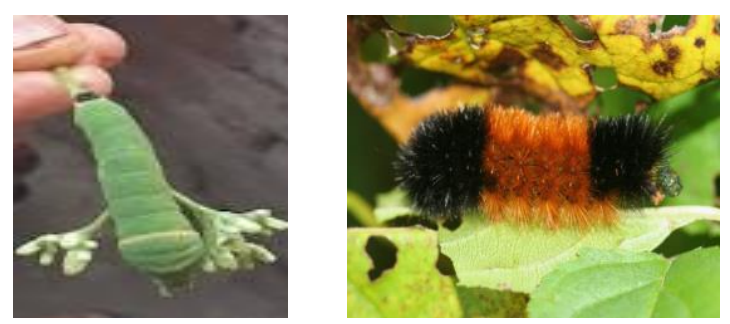
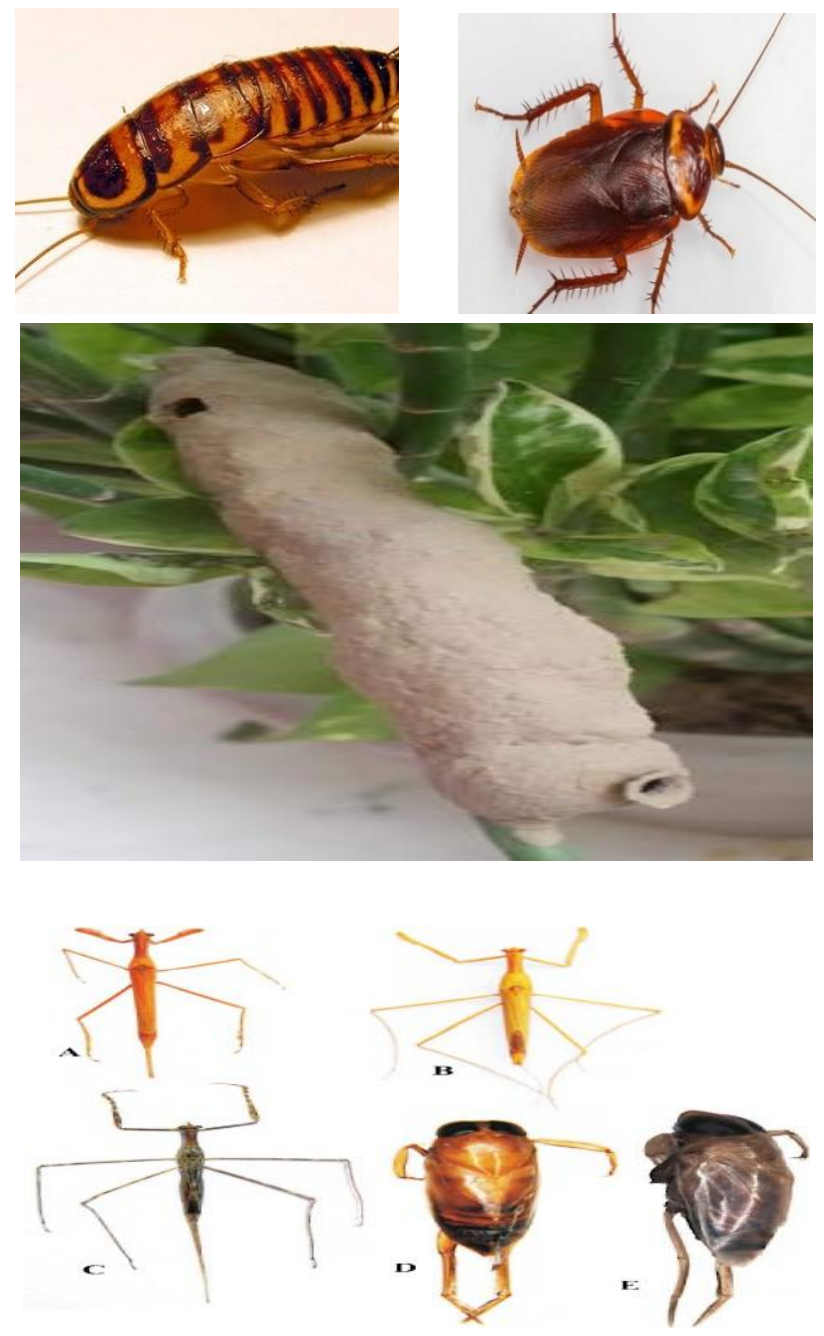

The various insect species were collected from the study area to identify the insect species and their diversity. Among them various insect species belonging to order Lepidoptera, Coleoptera, Hemiptera, Hymenoptera, Diptera, Dermaptera, Orthoptera, Odonata, Mantodea, and Isoptera were collected. The total identified species were 603 in number from 38 families and 10 orders. In which order Diptera identified with maximum number of species (153) with five families i.e. Syrphidae, Trypetidae, Muscidae, Culicidae, Asilidae in which Trypetidae is dominant and Dermaptera is with minimum number of species (02) with Labiduridae family .Hymenoptera (96) is the second rich diverse order with five families Vespidae, Xylocopidae, Apidae, Formicidae, Tenthredinidae in which Apidae is dominant.Order Hemiptera (91) is also rich in number with six families in which Reduviidae is 
dominant. Coleoptera is also rich diverse order with six families with (90) species in which Coccinellidae is dominant. Orthoptera with (66) species of three families in which Acrididae is dominant. Order lepidoptera identified with (55) species of six families in which Arctidae is dominant. Order Mantodea with (24) species of one family Mantiidae, Isoptera with (10) species of one family Termitidae and Odonata with (16) species of three families i.e. Coenagnonidae, Gomphidae and Aeshnidae.

This study of richness of insect diversity findings are similarly also shown in the Painkra, G. Thakare VG,
Zade VS, Hegde VD. Ground beetles (Coleoptera: Carabidae), Haldar, P., Bhandar, K. P., \& Nath, who studied Observations on food preferences of an Indian grasshopper Acrida exaltata (Walker)(Orthoptera: Acrididae, Parandhaman D. who worked on Diversity of butterflies in different habitats, Muhammad A. who worked on Diversity, Species Richness and Evenness of Moth Fauna etc.The present findings is made with accordance to the Painkra, G. P., \& Painkra, K. L. (2018).

Table 1: Occurrence of different insect diversity with their host:

\begin{tabular}{|c|c|c|c|c|c|c|}
\hline S.N & Order & $\begin{array}{l}\text { Family/S.Fa } \\
\text { mily }\end{array}$ & $\begin{array}{l}\text { Scientific } \\
\text { name }\end{array}$ & Common name & Hosts & $\begin{array}{l}\text { Occuren } \\
\text { ce }\end{array}$ \\
\hline 1 & $\begin{array}{l}\text { Lepidopter } \\
\text { a }\end{array}$ & Papilionidae & $\begin{array}{l}\text { Papilio } \\
\text { demoleus }\end{array}$ & Swallowtail butterfly & $\begin{array}{l}\text { Sweat orange and other } \\
\text { plant }\end{array}$ & 01 \\
\hline 2 & $\begin{array}{l}\text { Lepidopter } \\
\text { a }\end{array}$ & Dainidae & $\begin{array}{l}\text { Danaus } \\
\text { chrysippus }\end{array}$ & $\begin{array}{l}\text { Tigers/milkweeds/mo } \\
\text { narchs }\end{array}$ & Drier, wide open areas. & 12 \\
\hline 3 & $\begin{array}{l}\text { Lepidopter } \\
\text { a }\end{array}$ & Sphingidae & $\begin{array}{l}\text { Acherontia } \\
\text { styx }\end{array}$ & $\begin{array}{ll}\text { Sphingid } & \text { moth } \\
\text { /death's-head } & \text { hawk } \\
\text { moth. } & \end{array}$ & Food plants & 17 \\
\hline 4 & $\begin{array}{l}\text { Lepidopter } \\
\text { a }\end{array}$ & Saturnidae & $\begin{array}{l}\text { Anthermea } \\
\text { mylitta }\end{array}$ & $\begin{array}{l}\text { Tasar silkworm/Vanya } \\
\text { silkworm }\end{array}$ & $\begin{array}{l}\text { papaya, tapioca and } \\
\text { jetropha }\end{array}$ & 04 \\
\hline 5 & $\begin{array}{l}\text { Lepidopter } \\
\text { a }\end{array}$ & Arctidae & $\begin{array}{l}\text { Spilosoma } \\
\text { obliqua }\end{array}$ & Jute-hairy caterpillar. & Plant leaves & 20 \\
\hline 6 & $\begin{array}{l}\text { Lepidopter } \\
\text { a }\end{array}$ & Nocturidae & $\begin{array}{l}\text { Ergolis } \\
\text { merione }\end{array}$ & Orange butterfly. & Soil and monocot plants & 01 \\
\hline 7 & Coleoptera & Scarabaeidae & $\begin{array}{l}\text { Heliocopris } \\
\text { bucephalus }\end{array}$ & Elephant dung beetle. & $\begin{array}{l}\text { Rose,capcicumm,guava, } \\
\text { mango }\end{array}$ & 25 \\
\hline 8 & Coleoptera & $\begin{array}{l}\text { Melolonthai } \\
\text { nae }\end{array}$ & $\begin{array}{l}\text { Mylabris } \\
\text { pustulata }\end{array}$ & Hycleusbeetles & $\begin{array}{l}\text { Cofee,ginger } \\
\text { cinnamon. }\end{array}$ & 20 \\
\hline 9 & Coleoptera & Rutelinae & $\begin{array}{l}\text { Anomala } \\
\text { ruficapilla }\end{array}$ & $\begin{array}{ll}\text { Shining } & \text { leaf } \\
\text { chafersbeetle. } & \end{array}$ & leaves & 08 \\
\hline 10 & Coleoptera & Dytiscidae & $\begin{array}{l}\text { Copelatus } \\
\text { indicus }\end{array}$ & Diving beetle & Rice,Sugarcane & 11 \\
\hline 11 & Coleoptera & $\begin{array}{l}\text { Coccinellida } \\
\text { e }\end{array}$ & $\begin{array}{l}\text { Coccinella } \\
\text { septumpunct } \\
\text { ata }\end{array}$ & $\begin{array}{l}\text { Seven-spoted lady } \\
\text { bird/beetle. }\end{array}$ & $\begin{array}{l}\text { Tecton,grindis, Rose and } \\
\text { brinjal }\end{array}$ & 22 \\
\hline
\end{tabular}


Prerana Prakhar et al Int J Sci Res Sci \& Technol. September-October-2021, 8 (5) : 467-468

\begin{tabular}{|c|c|c|c|c|c|c|}
\hline 12 & Coleoptera & $\begin{array}{l}\text { Hydrophilid } \\
\text { ae }\end{array}$ & $\begin{array}{l}\text { Helochares } \\
\text { anchoralis }\end{array}$ & & Aquatic ecosystem & 04 \\
\hline 13 & Hemiptera & $\begin{array}{l}\text { Pyrrhocorid } \\
\text { ae }\end{array}$ & $\begin{array}{l}\text { Dysdercus } \\
\text { koengii }\end{array}$ & Red cotton stainer. & cotton, okra a & 13 \\
\hline 14 & Hemiptera & $\begin{array}{l}\text { Pentatomida } \\
\text { e }\end{array}$ & $\begin{array}{l}\text { Nezara } \\
\text { virudula }\end{array}$ & Greensting bug. & $\begin{array}{l}\text { Radish and cabbage } \\
\text { plants }\end{array}$ & 10 \\
\hline 15 & Hemiptera & Reduviidae & $\begin{array}{l}\text { Platymeris } \\
\text { laevicollis }\end{array}$ & Redspot assessin bug. & vertebrates & 28 \\
\hline 16 & Hemiptera & Delphacidae & $\begin{array}{l}\text { Sogotella } \\
\text { furcifera }\end{array}$ & Brown planthohopper & Corn and rice plants & 22 \\
\hline 17 & Hemiptera & Aphididae & $\begin{array}{l}\text { Lipaphis } \\
\text { erysimi }\end{array}$ & $\begin{array}{l}\text { Mustard aphid/turnip } \\
\text { aphid. }\end{array}$ & Food plants & 12 \\
\hline 18 & Hemiptera & Nepidae & $\begin{array}{l}\text { Laccotrephes } \\
\text { sp. }\end{array}$ & Water scorpion. & Aquatic ecosystem & 06 \\
\hline 19 & $\begin{array}{l}\text { Hymenopt } \\
\text { era }\end{array}$ & Vespidae & Vespa cincta & $\begin{array}{l}\text { Greater banded } \\
\text { hornet. }\end{array}$ & Crop plants & 21 \\
\hline 20 & $\begin{array}{l}\text { Hymenopt } \\
\text { era }\end{array}$ & Xylocopidae & $\begin{array}{l}\text { Xylocopa } \\
\text { fenestrata }\end{array}$ & Carpenter bee & Wood or other trees & 03 \\
\hline 21 & $\begin{array}{l}\text { Hymenopt } \\
\text { era }\end{array}$ & Apidae & $\begin{array}{l}\text { Apisdorsata, } \\
\text { A. indiaca }\end{array}$ & Honey bee & Floral plants & 48 \\
\hline 22 & $\begin{array}{l}\text { Hymenopt } \\
\text { era }\end{array}$ & Formicidae & $\begin{array}{l}\text { Oecophylla } \\
\text { smargdina }\end{array}$ & $\begin{array}{l}\text { Weaver ant/green tree } \\
\text { ant. }\end{array}$ & Floral plants & 18 \\
\hline 23 & $\begin{array}{l}\text { Hymenopt } \\
\text { era }\end{array}$ & $\begin{array}{l}\text { Tenthredini } \\
\text { dae }\end{array}$ & $\begin{array}{l}\text { Athalia } \\
\text { proxima }\end{array}$ & Mustard sawfly. & $\begin{array}{ll}\text { Herbaceous and } \\
\text { mustard plants }\end{array}$ & 06 \\
\hline 24 & $\begin{array}{l}\text { Orthopter } \\
\text { a }\end{array}$ & Tettigonidae & $\begin{array}{l}\text { Suthrophylla } \\
\text { sp }\end{array}$ & Spear grass. & $\begin{array}{l}\text { Calotropis, curry leaf, } \\
\text { grass }\end{array}$ & 14 \\
\hline 25 & $\begin{array}{l}\text { Orthopter } \\
\text { a }\end{array}$ & $\begin{array}{l}\text { Gryllotalpid } \\
\text { ae }\end{array}$ & $\begin{array}{l}\text { Gryllotalpa } \\
\text { africana }\end{array}$ & African mole cricket. & green plants & 22 \\
\hline 26 & $\begin{array}{l}\text { Orthopter } \\
\text { a }\end{array}$ & Acrididae & $\begin{array}{l}\text { Schistocerca } \\
\text { gregaria }\end{array}$ & $\begin{array}{l}\text { Graybird } \\
\text { grasshopper/desert } \\
\text { locust }\end{array}$ & Paddy fields & 30 \\
\hline 27 & $\begin{array}{l}\text { Dermapter } \\
\text { a }\end{array}$ & Labiduridae & $\begin{array}{l}\text { Labidura } \\
\text { riparia }\end{array}$ & Striped earwig & Potato plants & 02 \\
\hline 28 & Diptera & Syrphidae & $\begin{array}{l}\text { Syrphusbalte } \\
\text { atus }\end{array}$ & Marmalade hoverfly & Floral plants & 35 \\
\hline 29 & Diptera & Trypetidae & $\begin{array}{l}\text { Bactocera } \\
\text { cucurbitae }\end{array}$ & Melon fly & Fruit and flower plants & 60 \\
\hline 30 & Diptera & Muscidae & $\begin{array}{l}\text { Musca } \\
\text { domestica }\end{array}$ & $\begin{array}{l}\text { Housefly/Mouche } \\
\text { domestique. }\end{array}$ & Dairy and poultry & 48 \\
\hline 31 & Diptera & Culicidae & $\begin{array}{l}\text { Culiceta } \\
\text { longiareolata }\end{array}$ & Mosquito & $\begin{array}{l}\text { Animals of different } \\
\text { classes. }\end{array}$ & 06 \\
\hline
\end{tabular}


Prerana Prakhar et al Int J Sci Res Sci \& Technol. September-October-2021, 8 (5) : 467-468

\begin{tabular}{|l|l|l|l|l|l|l|}
\hline 33 & Diptera & Asilidae & Zosteria sp. & Eelgrass/seawrack. & Parasite of honeybees & 04 \\
\hline 34 & Mantodea & Mantidae & $\begin{array}{l}\text { Mantis } \\
\text { religiosa }\end{array}$ & Mantis & Leaves of crops. & 24 \\
\hline 35 & Isoptera & Termitidae & $\begin{array}{l}\text { Odontotermi } \\
\text { s obesus }\end{array}$ & Termite & Crop plants and trees. & 10 \\
\hline 36 & Odonata & $\begin{array}{l}\text { Coenagnoni } \\
\text { dae }\end{array}$ & $\begin{array}{l}\text { Nehalennia } \\
\text { gracilis }\end{array}$ & $\begin{array}{l}\text { Narrow-winged } \\
\text { damselfly. }\end{array}$ & $\begin{array}{l}\text { open bodies of fresh } \\
\text { water }\end{array}$ & 05 \\
\hline 37 & Odonata & Aeshnidae & $\begin{array}{l}\text { Anaxparthan } \\
\text { ope }\end{array}$ & $\begin{array}{l}\text { Lesser Emperor } \\
\text { dragonfly }\end{array}$ & Freshwater habitats & 04 \\
\hline 38 & Odonata & Gomphidae & $\begin{array}{l}\text { Lindenia } \\
\text { tetraphylla }\end{array}$ & Bladetail dragonfly. & Green water bodies. & 07 \\
\hline $\begin{array}{l}\text { Tot } \\
\text { al }\end{array}$ & 10 & 38 & & & 603 \\
\hline
\end{tabular}

\section{IV.CONCLUSION}

Biodiversity of insects is good in Raipur due to ample quantity of different flora and fauna. Here good vegetation in villages area where kharif and Rabi crops grown by the farmers and abundance of host plant and animals are in the urban area. Therefore availability of above flora and fauna is good shelter for survival of organisms which provide clarification of habit and habitat of different insect species and its impact on the biotic and abiotic factor which influence the conservation of biodiversity.

\section{REFERENCES}

[1]. INSECT BIODIVERSITY; SCIENCE AND SOCIETY. BY ROBERT G.;PETER H. ADLER.

[2]. Johri, P. K., \& Johri, R. (2010). Application of Dyar's Law in Indian Predaceous Earwig, Labidura Riparia (Pallas) form Bengalensis (Dohrn)(Dermaptera: Labiduridae). Indian Journal of Entomology, 72(2), 111-113.

[3]. Paulraj, M. G., Anbalagan, V., \& Ignacimuthu, S. (2009). Distribution of Grasshoppers (Insecta: Orthoptera) among different host plants and habitats in two districts of Tamil Nadu, India. Journal of threatened Taxa, 230-233.

[4]. Fursov, V. N. (2004). New data on the biology and distribution of the Lathromeroidea silvarum Nowicki, 1937 (Chalcidoidea:

Trichogrammatidae)-an egg parasitoid of water beetles (Hydrophilidae and Dytiscidae). Russian Entomological Journal, 13(3), 165-169.

[5]. Thakare VG, Zade VS, Hegde VD. Ground beetles (Coleoptera: Carabidae) of Melghat Tiger Reserve, Central India. New Biological Reports. 2013;

[6]. Dubey, V. (2004). Ecology of jungle rice (Echinoch/oa co/onum), a weed of the rice agroecosystem: a case study in Bilaspur (Chhattishgarh). International Rice Research Notes, 29(2), 1-1.

[7]. District survey report 2016. Ministry of Environment, forest and climate change. Govt.of Chhattishgarh.

[8]. Painkra, G. P., \& Painkra, K. L. (2018). Biodiversity of insects in Ambikapur of Chhattisgarh.

[9]. Thakare VG, Zade VS, Hegde VD. Ground beetles (Coleoptera: Carabidae) of Melghat Tiger Reserve, Central India. New Biological Reports. 2013; 2(2):173176.

[10]. Beeson, C.F.C., 1941. The Ecology and Control of the Forest Insects of India and Neighboring Countries.pp: 1-767.

[11]. Muhammad A. Diversity, Species Richness and Evenness of Moth Fauna of Peshawar. Pakistan Entomological. 2009; 31:2. 8 
[12]. Kulshrestha R, Jain NA. note on the biodiversity of insects collected from a college campus of Jhalawar District, Rajasthan. Bioscience Biotechnology Research Communications. 2016; 9(2):327-330.

[13]. Humphrey, J. W., Hawes, C., Peace, A. J., Ferris-Kaan, R., \& Jukes, M. R. (1999). Relationships between insect diversity and habitat characteristics in plantation forests. Forest ecology and management, 113(1), 11-21.

[14]. Tiwari, P., \& Soni, I. (2015). Study of vegetation in Government Rajiv Lochan College Campus Rajim, District Gariaband (Chhattisgarh). Indian Journal of Life Sciences, 5(1), 89-95.

\section{Cite this article as :}

Prerana Prakhar, Dr. Manoj Singh, Dr. R. K. Agrawal, "A Study of Insect Diversity in Different Habitats Found in Nearby Locality of Raipur, Chhattisgarh", International Journal of Scientific Research in Science and Technology (IJSRST), Online ISSN : 2395-602X, Print ISSN : 2395-6011, Volume 8 Issue 5, pp. 467-468, September-October 2021. Available at doi : https://doi.org/10.32628/IJSRST21831104 Journal URL : https://ijsrst.com/IJSRST21831104 